\title{
The Empirical Study on CEO Power and Investment Efficiency Sun-Lei YANG ${ }^{a,{ }^{*}}$, Xiong-Fei LIU ${ }^{b}$

\author{
School of Accounting Wuhan Textile University, Wuhan, Hubei, China
} \\ a50495815@qq.com, b228327730@qq.com \\ *Corresponding author
}

Keywords: CEO power, Investment efficiency, Power protection.

\begin{abstract}
In the economic organization, CEO is the highest administrative official responsible for the routine business in an enterprise. The size of the CEO's power has great impact on CEO's decision making, and the interest of stakeholders. But, academia is inconsistent to the influence of CEO power, one is "power beyond" and the other is "power protection". "Power beyond" thinks too much power can let CEO give up the company's interests for personal gain. "Power protection" thinks high power of CEO is advantageous to the development of the company. This paper builds comprehensive measure CEO rights of four dimensions first, and examines that CEO power influence on investment efficiency with method of multivariate regression analysis, by using 2010-2014 data of Chinese listed companies. The conclusion shows that the greater the CEO power is, the higher the investment efficiency will be. This paper results support "power protection "and provide empirical evidence for the theory "power protection ".
\end{abstract}

\section{Introduction}

In the economic organization, chief executive officer(CEO)is the highest administrative official responsible for the routine business in an enterprise. It can also be called administrative president, general manager, or the highest executive. As the manager of a company, each decision making of CEO has relations to the fate of the company. The size of the CEO's power has great impact on CEO's decision making, and the interest of stakeholders. There are two conflicting claims about CEO in academia, namely "power beyond" and " power protection". "Power beyond" thinks CEO is "economic man "that who has conflict of shareholder interests, that is to say, the individual interests first, too much power can let CEO give up the company's interests for personal gain. "Power protection" thinks CEO has a spirit of collectivism, is a "social person "who is consistent with shareholder interests, high power of CEO is advantageous to the development of trust and cooperation relations, to promote the development of the company. So which theory hypothesis is more applicable for CEO of Chinese listed company? What's the impact of CEO power on the investment decision of a company in Chinese listed companies? This article builds comprehensive measure CEO rights of four dimensions, and researches empirically the impact of CEO power on investment efficiency by using the data from 2010 to 2014.

\section{Literature Review and Research Hypothesis}

\section{CEO Power}

Under the condition of market economy, the CEO's power profoundly affects the business and economic development. Zhang Qia and Yuan Tianrong (2013) found that the greater CEO power is, M\&A are more likely to be promoting, and achieve high private benefits [1]. Abernethy, Margaret etc. (2015) studied the CEO power effect on the adjustment of the compensation system, the study showed that company's powerful CEO is more inclined to adopt more easily in the pay system to complete the performance targets [2]. Zhong-xin wu and Yan sisi (2016) has carried on the empirical research of the relationship d between CEO power and enterprise performance, research shows CEO power influence mechanism of enterprise performance [3]. Zhijun li and Mingxian Li (2012) found that after the bank holdings, the company's value will be higher than before the bank 
holdings and bank holding company of investment efficiency on the value of the company's positive effect is greater than the non-bank holding company, so the research shows that bank ownership improve the efficiency of the company's investment and the value of the company ${ }^{[4]}$.

\section{Investment Efficiency}

In recent years, researches on contributing factors of investment efficiency are becoming more considerable, and more perfect. Xing Liu and Kangtao Ye(2013)did a research on the enterprise tax avoidance activities' impact on investment efficiency. The result shows that the degree of enterprise's tax avoidance has significant positive correlation to investment efficiency. This positive correlation is mainly in form of over-investment caused by tax avoidance, and a good corporate governance mechanism can restrain the impact of this [5]. Audrey Wen etc.(2015)did a research on the impact of IAS 27 on companies' investment efficiency, the result shows that companies' investment efficiency increase significantly after adopting IAS 27 [6]. By reviewing former research, we can see that researches on CEO power and investment efficiency are becoming more and more perfect. But researches on the relationship of CEO power and investment efficiency are limited and imperfect. In this text, based on the sample collected, we research the impact of CEO power on investment efficiency after full measurement of CEO power and investment efficiency, in order to enrich the pertinent literature.

\section{Research Hypothesis}

In this paper, we research the relationship of CEO power and investment efficiency. Although two statements of CEO in the academic community, there is "Power Beyond" and "power protection" .According to "Power beyond" , CEO is "economic man "that who has conflict of shareholder interests, that is to say, the individual interests first, too much power can let CEO give up the company's interests for personal gain. Highly authorized to CEO will investment inefficiently, so we put forward the hypothesis $1 \mathrm{a}$.

Hypothesis 1a: CEO power has negative correlation to investment efficiency. If CEO power becomes greater, investment efficiency will become lower.

According to "power protection", highly authorized to CEO will benefit the development of trust and cooperation, promoting the development of companies. With good sense of trust and cooperation, CEO can make better decision, including wiser investment decision, thus decreasing the inefficient investment, making investment more efficient. So we put forward the hypothesis $1 \mathrm{~b}$.

Hypothesis 1b: CEO power has positive correlation to investment efficiency. If CEO power becomes greater, investment efficiency will become higher.

\section{Research Design}

\section{Sources of Data}

The data involved is mainly from CSMAR, from 2010 to 2014. In statistics and analysis, we remove missing data. To ensure the availability and integrity of data, we finally retain 7434 sample data. We adopt Excel2003 and STATA13 to assist the systemizing and analysis of data.

\section{Choice of Variables}

In this article, we consider CEO power as explanatory variable, and consider investment efficiency as explained variable. On account of the fact that investment efficiency has a lot of influencing factor, we choose some important influencing factor as control variable.

\section{Explained Variable}

Explained variable is investment efficiency(efficiency), to measure companies' condition of investment efficiency. We use Richardson's(2006)model, to estimate investment efficiency by estimating investment condition. The model is shown below. 
Investt $=\beta 0+\beta 1$ Growtht $-1+\beta 2$ Levt $-1+\beta 3$ Casht $-1+\beta 4$ Aget $-1+\beta 5$ Sizet $-1+\beta 6$ Returnst $-1+$ $\beta 7$ Investt- $1+\varepsilon$

In equation (1), Invest represents additional investment; we can measure this using capital spending value, mergers and acquisitions spending value, sale of long-term assets value, depreciation value, and total asset value in one year. And we can calculate through formula Invest $=$ (capital spending value + mergers and acquisitions spending value - sale of long-term assets value depreciation value)/ total asset value. Capital spending value can be acquired from item of expenditure of construction of fixed assets, intangible assets and other long-term assets from statement of cash flow (direct method). Mergers and acquisitions spending value can be acquired from item of net cash from subsidiaries and other business entity from statement of cash flow (direct method). Sale of long-term assets value can be acquired from item of net cash from disposal of fixed assets, intangible assets and other long-term assets from statement of cash flow (direct method). Depreciation value can be acquired from item of the current depreciation expense from statement of cash flow (indirect method).Growth represents companies' investment opportunity; this can be acquired by calculating the growth rate of operating income of the previous period. Lev represents companies' asset-liability ratio, this can be acquired by calculating the value of total liabilities divided by total assets. Age represents companies' listed years; this can be acquired by calculating natural logarithm (base e) of companies' listed years. Size represents scale of company; this can be acquired by calculating natural logarithm of total assets. Return represents annual returns of companies' shares; this can be acquired by calculating individual stocks returns of cash dividends reinvested. In addition, equation (1) introduces control of annual effect and industrial effect. Through equation 1, residual (e) can be estimated. Positive value represents over-investment, negative value represents Under-investment. So the absolute value of this can be considered as index of measuring investment efficiency. So the absolute value of this (efficiency) can be considered as index of measuring companies' investment efficiency. The more the value is, the higher degree the inefficient investment has, the lower the investment efficiency is.

\section{Explanatory Variable}

Explanatory variable is CEO(CEOPower), to measure the size of CEO power. Through the review of the former research on how to measure managers' power, we adopt 4 main indexes. Based on data from CSMAR, we did the measurement of CEO power. The indexes can be listed below.

Table1. Measuring dimensions and indexes of CEO power

\begin{tabular}{|l|l|l|}
\hline Dimensions & Indexes & Meaning of indexes \\
\hline \multirow{2}{*}{ Organization power } & dual & Chairman as part time job(yes $\rightarrow 1, \mathrm{No} \rightarrow 0)$ \\
\cline { 2 - 3 } & insider director & Inside director(yes $\rightarrow 1, \mathrm{No} \rightarrow 0)$ \\
\hline Expert power & rank & Senior professional title $(\mathrm{yes} \rightarrow 1, \mathrm{No} \rightarrow 0)$ \\
\hline Ownership power & CEO share & Hold equity of own company $(\mathrm{yes} \rightarrow 1, \mathrm{No} \rightarrow 0)$ \\
\hline Reputation power & education & High academic qualifications $(\mathrm{yes} \rightarrow 1, \mathrm{No} \rightarrow 0)$ \\
\cline { 2 - 3 } & part-time job & Part-time job of other company $(\mathrm{yes} \rightarrow 1, \mathrm{No} \rightarrow 0)$ \\
\hline
\end{tabular}

Shown in Table 1, CEO power can be measured through 4 main dimensions, organization power, expert power, ownership power, reputation power. Among these, organization power, is measured by indexes of dual (Chairman as part time job) and insider director (Inside director), and the measurement of organization power can be acquired by calculate average value of these two indexes. Expert power is measured by index of rank (Senior professional title). Ownership power is measured by index of CEO share (Hold equity of own company). Reputation power is measured by indexes of education (High academic qualifications) and part-time job (Part-time job of other company), and the measurement of organization power can be acquired by calculate 
average value of these two indexes. The values of these indexes derive from CSMAR. Value of CEO power (CEOPower) can be measured by calculating the average value of these 4 main dimensions after the values of the 4 main dimensions are acquired. The greater the value is, the greater the CEO power is.

\section{Control Variable}

There are many important factors influencing the researches of investment efficiency. The research must introduce some important factors for controlling. We introduce listed years(Age),asset-liability ratio(lev), return on assets(roa)to control the research.

\section{Model Building}

In consideration of controlling common factors influencing investment efficiency, we adopt multiple regression analysis way and built the linear regression model below.

$$
\text { efficiency }=\beta 0+\beta 1 \text { CEOPower }+\beta 2 \text { Age }+\beta 3 \text { lev }+\beta 4 \text { roa }+\varepsilon
$$

In equation(2), efficiency is explained variable, representing investment efficiency. CEOPower is explanatory variable, representing CEO power. Age is listed years of companies. lev represents asset-liability ratio, measured by ratio of total liabilities and total assets. roa represents return on assets, measured by ratio of net profit and total asset. $\beta 0$ is constant term. $\varepsilon$ is amount of random error.

\section{The Empirical Result Analysis}

\section{Descriptive Analysis}

Descriptive statistics of sample are listed in Table 2.

Table 2. Descriptive statistics chart of sample

\begin{tabular}{|c|c|c|c|c|c|}
\hline Variable & Obs & Mean & Std. Dev. & Min & Max \\
\hline efficiency & 7434 & 0.0581837 & 0.1544377 & 0.0000457 & 11.58658 \\
\hline CEOPower & 7434 & 0.2822505 & 0.229515 & 0 & 0.875 \\
\hline Age & 7434 & 2.325293 & 0.5939448 & 1.098612 & 3.218876 \\
\hline lev & 74344 & 0.514155 & 0.745438 & 0.0070799 & 46.15936 \\
\hline roa & 7434 & 0.0292963 & 0.6429935 & -48.31592 & 22.00512 \\
\hline
\end{tabular}

From Table 2, we can see investment efficiency (efficiency) have a large difference among minimum value and maximum value. The minimum value is 0.0000457 ; this means a high investment efficiency. The maximum value is 11.58658; this means an obvious inefficient investment, and a low investment efficiency. For CEO power (CEOPower), it has a value range from 0 to 1 , and it has a large difference among minimum value and maximum value. This means a great difference among CEO power in different companies. The minimum value is 0; this means a low level of CEO power. The maximum value is 0.875 , this means a high level. For listed years of companies (Age), the mean value is 2.325293, the minimum value is 1.098612 , the maximum value is 3.218876, and the standard deviation is 0.5939448 . These tell us that there exists only a little difference in listed years of companies. For asset-liability ratio (lev), the mean value is 0.514155 . This means that return on assets (roa)of sample companies is relatively appropriate. Mean value of return on assets is 0.0292963 , meaning a relatively low return on assets among sample companies, and it has a large difference among minimum value and maximum value. 


\section{Correlation Analysis}

Table 3. Correlation analysis of variables

\begin{tabular}{|c|c|c|c|c|c|}
\hline & efficiency & CEOPower & Age & lev & roa \\
\hline efficiency & 1.0000 & & & & \\
\hline CEOPower & -0.0025 & 1.0000 & & & \\
\hline Age & -0.0173 & $-0.322^{* * *}$ & 1.0000 & & \\
\hline lev & $0.088^{* * *}$ & $-0.056^{* * *}$ & $0.1116^{* * *}$ & 1.0000 & \\
\hline roa & $0.109^{* * *}$ & 0.0186 & -0.0159 & $-0.689 * * *$ & 1.0000 \\
\hline \multicolumn{7}{|c|}{$* * * \mathrm{P}<0.01, * * \mathrm{P}<0.05, * \mathrm{P}<0.1$} \\
\end{tabular}

From Table 3, we can see that the correlation coefficient of investment efficiency and CEO power is -0.0025 , showing a negative correlation. This result provides a preliminary identification of our hypothesis. And we can acquire the relationship of investment efficiency and other control variable. The correlation coefficient of investment efficiency and listed years is -0.0173, representing a negative correlation. The correlation coefficient of investment efficiency and asset-liability ratio is 0.0881 , representing a positive correlation. The correlation coefficient of investment efficiency and return on assets is 0.1088 , representing a positive correlation.

\section{Regression Analysis}

Table 4. Regression result of CEO power and investment efficiency

\begin{tabular}{|c|l|l|l|}
\hline variables & coefficient & $\mathrm{T}$ & $\mathrm{P}$ \\
\hline CEOPower & $-0.0128152^{*}$ & -1.66 & 0.097 \\
\hline Age & $-0.0087394^{* * *}$ & -2.82 & 0.005 \\
\hline lev & $0.0702958^{* * *}$ & 22.40 & 0.000 \\
\hline roa & $0.0816684 * * *$ & 22.66 & 0.000 \\
\hline Constant & 0.0502748 & 0.78 & 0.436 \\
\hline observations & 7434 & & \\
\hline R-squared & 0.1471 & & \\
\hline
\end{tabular}

Shown in Table 4, value of mathematical model R2 is 0.1471 , and from table 4, P values of this model are all less than 0.1. These show that this model is significant, and has statistical significance. Table 5 lists the result of multiple regressions. The result shows that the investment efficiency (efficiency) and CEO power (CEOPower) represent a negative correlation, and at the 10\% significance level. This means that if the value of CEOPower increase, the value of efficiency will decrease, showing the fact that the greater the CEO power is, the less the inefficient investments will exist, the higher the investment efficiency will be. This confirms our hypothesis $1 \mathrm{~b}$. For control variable, based on the results above, investment efficiency (efficiency) has significant negative correlation to listed years (Age), investment efficiency (efficiency) has significant positive correlation to asset-liability ratio (lev), investment efficiency (efficiency) has significant positive correlation to return on assets (roa).

\section{Robustness Test}

We replace return on assets with return on equity, and test the regression model of investment efficiency and CEO power. The correlation coefficient of investment efficiency and CEO power is -0.0118648, also showing a negative correlation between investment efficiency and CEO 
power(CEOPower). This confirms the result again that the greater the CEO power is, the less the inefficient investments will exist, and the higher the investment efficiency will be. This confirms our hypothesis again. So the empirical results in this text have certain robustness.

\section{Conclusions}

This article involves relevant data from CSMAR from 2010 to 2014 as sample, analyzing the impact of CEO power on investment efficiency. We draw a conclusion after the analysis that there exists a positive correlation between investment efficiency and CEO power, the greater the CEO power is, the higher the investment efficiency will be. The conclusion of this text confirms the universally truth of the saying "Power protection". That is to say, CEOs generally have collectivism spirits; they are social being who has consistent interests with shareholders. Therefore, CEO should be granted full of trust, and high level of power, in order to motivate CEO, making them full of enthusiasm. This approach can help CEO reach their full potential, and strengthen the control of company, thus improve companies' investment efficiency, guarantee the interests of the shareholders, and promote the development of the company.

\section{References}

[1] Zhang Qia, Yuan Tianrong. (2013).CEO power, private benefits and M\&A motivation - based on the empirical study of listed companies in China. Journal of financial research. 33 (4) 6:101-122(In Chinese).

[2] Margaret A. Abernethy, Yu Flora Kuang, Bo Qin. (2015).The Influence of CEO Power on Compensation Contract Design. THE ACCOUNTING REVIEW,90:120-129.

[3] Zhong-xin Wu Yansisi.(2016). CEO power, media attention and enterprise performance. Journal of accounting monthly, 3 (4) : 3-8(In Chinese).

[4] Zhijun Li, Li Ming-xian. (2012).Bank holding, investment efficiency and the value of the company. Journal of yunnan university of finance and economics.4:97-104(In Chinese).

[5] Liu Xing Ye Kangtao.(2013). Will Companies' Tax Avoidance Activities Affect investment efficiency? [J]. Accounting Research Study.6:47—53(In Chinese).

[6] Audrey Wen-hsin Hsu, Boochun Jung, and Hamid Pourjalali.(2015). Does International Accounting Standard No. 27 Improve Investment Efficiency? . Journal of Accounting, Auditing \& Finance.30(4):484-508(In Chinese). 